\title{
白血球抗体検出のための 5 系統の血液細胞を同時に測定する 新たなフローサイトメトリー法
}

\begin{tabular}{|c|c|c|c|c|c|c|c|c|}
\hline 宣樹1) & 小島 & 芳隆 ${ }^{1)}$ & 平山 & 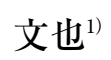 & 保井 & 一太 ${ }^{1)}$ & 谷上 & 純子 ${ }^{11}$ \\
\hline 泰雄1) & 吉村 & 敬次 ${ }^{1)}$ & 田端 & 信忠 ${ }^{2)}$ & 坂田 & 尚己 ${ }^{2)}$ & 谷 & 慶彦1) \\
\hline
\end{tabular}

白血球抗体を検出する方法として，フローサイトメトリー（FCM）法が一般的に用いられているが，同方法には いくつかの欠点がある. その一つは, 好中球や単球抗のバックグラウンド蛍光が高い事, また, 抗体の特異性の同 定には好中球，単球のみならず $\mathrm{T}$-リンパ球，B-リンパ球，血小板といった他の血液細胞との反応性も同時に検討す る必要がある事である. その為, 我々は低バックグラウンドで, かつ, 4 系統の白血球と血小板を同時に測定する方 法の樹立を試みたので報告する．FCM 解析にはエチレンジアミン 4 酢酸(EDTA)採血した全血を試料として用い, 5 系統細胞の識別は $\mathrm{FSC} / \mathrm{SSC}$ 分布と CD4，CD20，CD14 の発現の有無を基に行なった. その結果, 抗 HNA (human neutrophil antigen) 1b 血清を HNA 1b 陽性細胞と反応させた場合には, 好中球のみが陽性となり,抗 Naka (抗 CD36) 血清と反応させた場合には, 血小板と単球が陽性となった. 好中球と単球のバックグラウンドは十分に低くなった. また，HLA Class II の抗血清を用いたところ，B リンパ球と単球が陽性となり，HLA Class I の抗血清では 5 系統の 細胞が陽性であった.

キーワード： 5 系統細胞，フローサイトメトリー，白血球抗体，全血

本論文内容は, Transfusion Medicine 誌編集長および Blackwell Publishing 社の許可のもと, Transfusion Medicine 第 16 巻 第 2 号 111 頁-118 頁，2006 年に最初に掲載された論文に基づき作製したものである. (This article is based on a study first reported in the paper : N. Matsuyama, Y. Kojima, F. Hirayama, K. Yasui, A Taniue, Y. Fukumori, K. Yoshimura, N. Tabata, N. Sakata, Y. Tani and H. Shibata : Simultaneous five cell-lineage flow cytometric analysis system for detection of leucocyte antibodies. Transfusion Medicine. 16(3)111$118,2006)$

\section{はじめに}

白血球抗体は非溶血性輸血副作用，とりわけ輸血関 連急性肺障害（TRALI）の主な原因の一つと考えられ ている12).これまで HLA Class I 抗体, HLA Class II 抗体と TRALI との関わりが主に報告されているが(へ), 最近では, 単球抗体の関与も指摘されており ${ }^{10)}$, それら を検索することは重要である. 現在, 白血球抗体の検 出，同定および交差試験を行う方法としてフローサイ トメトリー(FCM) 法が一般的に用いられているが"11, 同方法にはいくつかの欠点がある。 その一つは，好中 球抗体や単球抗体を検出する際に, 同細胞の高いバッ クグラウンド蛍光により，その検出がしばしば困難に なることである. 特に, 単球のバックグラウンドは高 く，これを抑えるには，その原因となる FcyR I を予め
除去する処置が必要である ${ }^{10122}$. また, 抗体の特異性の 同定には好中球，単球のみならず T-リンパ球，B-リン パ球，血小板といった他の血液細胞との反応性も同時 に検討する必要がある。 そのため我々は，上記欠点を 克服した新規 $\mathrm{FCM}$ 法の樹立を試みたので報告する.

従来法では赤血球と血漿を除去した試料（解析対象 の血液細胞を精製または粗精製した試料)を用いるが, 本研究では, 以下の理由により, 全血そのものを試料 としている．1）パネル細胞由来陰性コントロール(パ ネル自己血清) と白血球抗体陽性血清(陽性コントロー ル）を用いて染色したところ, 好中球や特に単球にお いて, 陰性コントロールの值が高くなり, 陽性コント ロールとの差が認められなくなる現象が少なからずあっ た. 我々はこの現象について, 試料から血漿を除去し

1）大阪府赤十字血液センター

2) 近畿大学医学部付属病院小児科

〔受付日：2006 年 5 月 30 日, 受理日：2007 年 2 月 23 日〕 
た事が, 高バックグラウンドを招いたのであり，全血 を試料として用いる事により，全血に含まれる血漿成 分が, バックグラウンドが高くなるのを抑制するので はないかと推測した. 尚, 全血試料は検査操作を簡便 にするとともに，種々の血液細胞の機能評価試験に既 に用いられている ${ }^{1314)}$.2) HLA Class I 抗体や HLA Class II 抗体, HNA-1 抗体等の白血球抗体は, 血液細胞上に 発現する抗原だけでなく，血漿中に存在する可溶型抗 原とも反応する可能性があり ${ }^{1516)}$, より本来の輸血の状 況を再現できる事になると考えた.

\section{方 法}

\section{1）全血試料の準備}

用いた全血試料は，予めHLA Class I, HLA Class IIおよびHNA-1 タイプ既知の大阪府赤十字血液センター 職員由来のものを使用し, その採血時には抗凝固剂と して acid citrate dextrose (ACD) もしくは ethylene diamine tetraacetic acid（EDTA）を用いた。また，一 部の実験では同職員由来の血液より精製した血小板お よび好中球を用いた．血小板は ACD 採血した全血を $200 \times \mathrm{g} 20$ 分間, 遠心分離し, 得られた Platelet-rich plasma (PRP) より回収した.一方, 好中球は Polymorphprep (AXIS-SHIELD PoC ASOslo, Norway) 用いた比重遠心法により精製し, $0.1 \%$ ウシ血清アルブ ミンを添加したPBS (PBS/BSA) に浮遊させ, 実験に 用いた。

\section{2）被検血清}

非溶血性輸血副作用症例，血小板輸血不応答症例患 者, 新生児同種免疫性血小板減少症症例あるいは possible TRALI 症例（1）由来の白血球抗体陽性血清を被 検血清として用いた．被検血清中に含まれる白血球抗 体の特異性は, 予め抗ヒトグロブリンリンパ球細胞毒 試験 $(\text { AHG-LCT })^{17)}$, MPHA ${ }^{18)}$, LABScreen ${ }^{\circledR}$ (One Lambda Inc, Canoga Park, CA，USA）を用いて決定 した。また，陰性血清はパネル細胞由来の血清（自己 血清）を用いた。

\section{3） FCM による 5 系統血液細胞の解析}

EDTA 採血した全血 $50 \mu l$ と被検血清 (もしくは陰性 血清) $10 \mu l$ を $0.8 \mathrm{~m} l$ 96-well storage plate(Nippon Genetics Co Ltd, Tokyo, Japan) 中で混合し， $4^{\circ} \mathrm{C}, 15$ 分間 反応させた（別途記載がない場合はこの条件で実験を 行い, 被検血清を希釈する場合は PBS/BSA に $10 \mathrm{mM}$ EDTA を添加した PBS/BSA/EDTAを用いた). 反応 後, PBS/BSA/EDTA にて 2 回洗浄し, FITC 標識ウサ ギ抗ヒト $\operatorname{IgGF}(\mathrm{ab})_{2}$ (DAKO Cytomation, Glostrup, Denmark)を $20 \mu \mathrm{l}$ 加え, $4^{\circ} \mathrm{C}, 15$ 分間染色した. 次に, 赤血球を溶血させる為に, $700 \mu l$ の BD FACS ${ }^{\mathrm{TM}} \mathrm{Ly}$ sing Solution (BD Biosciences, San Jose, CA, USA) を加
え, 室温にて 10 分間反応させ, PBS/BSA/EDTA で 1 回洗浄後, 2 次抗体の残余結合部位をブロックする為に, マウス血清（DAKO Cytomation）を $10 \mu l$ 加え, $4^{\circ} \mathrm{C}$, 10 分間反応させた. その後, PE 標識抗ヒト CD4 モノ クロナール抗体(BD Biosciences), PE 標識抗ヒト CD20 モノクロナール抗体 (BD Biosciences), PerCP 標識抗 ヒト CD14 モノクロナール抗体 (BD Biosciences) で更 に $4^{\circ} \mathrm{C}, 15$ 分間染色し, FACScalibur(BD Biosciences) を用いて，測定を行なった。

また,一部の実験では, 試料を ACD 採血した全血と し，洗浄バッファーとして PBS/BSA を用いた.

本法において, T-リンパ球マーカーとして抗ヒト CD3 モノクロナール抗体を使用せずに, 抗ヒト CD4 モノク ロナール抗体を使用している，その理由は予備実験に おいて, CD8 陽性 T-リンパ球は, しばしば, 高バック グラウンドであったが，それに対し，CD4 陽性 T-リン パ球は低バックグラウンドで安定していた為である.

上記方法による代表的な FCM プロファイルを Fig. 1 に, そこで用いた各種血液細胞の識別ゲートを Table 1 にそれぞれ示した. R1 領域を血小板, R2 領域を好中 球とし, R3 および R5 領域の両方に属する血液細胞を CD4 陽性 T-リンパ球, R3 および R6 領域の血液細胞を $\mathrm{CD} 20$ 陽性 B-リンパ球とした. T-リンパ球と B-リンパ 球を識別する為に, PE-抗ヒト CD4 モノクロナール抗 体, PE-抗ヒト CD20 モノクロナール抗体を用いている が, これは予め検討を行い, FL2(PE) 領域が 3 ポピュ レーション (CD4 陽性群, CD20 陽性群, CD4, CD20 陰性群）になるように，各抗体濃度を調整した（data not shown). 単球については, FSC/SSC で決定した R4 領域と CD14 抗原が陽性の R7 領域の双方に属する血液 細胞とした.

一部の実験では，上記条件を以下の通りに部分的に 変更し, 実験を行った. FITC 標識 isotype control(BD biosciences), FITC 標識抗ヒト CD36 モノクロナール 抗体 (BD biosciences), FITC 標識抗ヒト CD41a モノ クロナール抗体 (BD biosciences) を用いて血液細胞を 染色した. 96-well round bottom plate (Corning Incorporated, Corning, NY, USA)を用い, 血液細胞を各 抗体で染色後, BD FACS ${ }^{\mathrm{TM}}$ Lysing Solutionを $200 \mu \mathrm{l}$ 加え, 赤血球を溶血させた.

\section{4) 好中球と immune complex の結合}

EDTA 採血した全血 $50 \mu l$ とビオチン標識マウス抗ヒ トHLA-DR モノクロナール抗体 (Beckman Coulter, CA，USA）を混合し， $4^{\circ} \mathrm{C}, 15$ 分間反応後, リンパ球 および好中球に，それぞれ直接および間接的（全血の 血漿成分に含まれる可溶型 HLA-DR 抗原が, 添加され た HLA-DR 抗体と反応し, immune complex を形成し, それが Fc $\gamma \mathrm{R}$ を介して好中球に間接的に結合)に結合し 
A

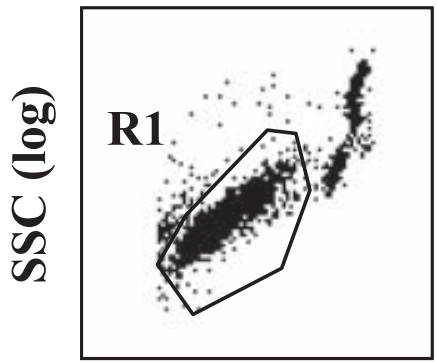

FSC $(\log )$

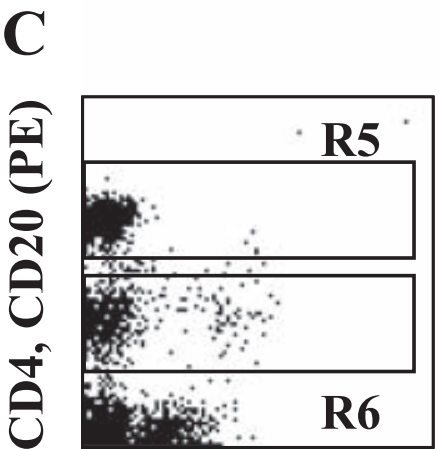

FITC

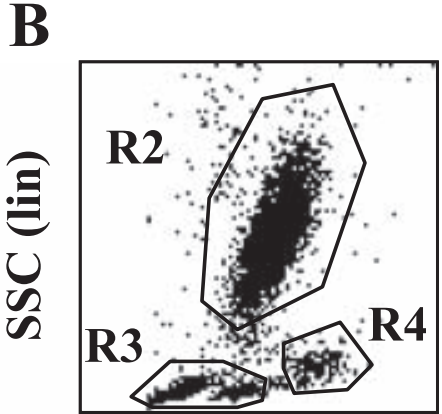

FSC (lin)

D

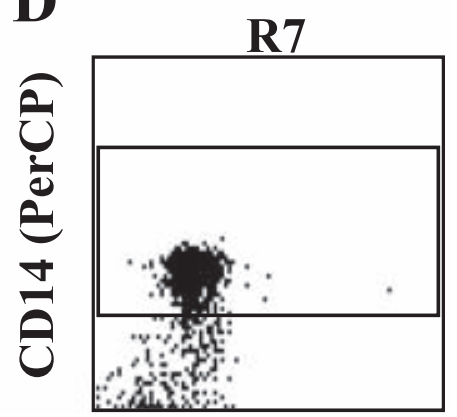

FITC

Fig. 1 Gates utilized to determine 5 lineage cells. Cells in the region $\mathrm{R} 1$ and $\mathrm{R} 2$ were regarded as platelets and neutrophils, respectively. Cells in the regions $\mathrm{R} 3$ and $\mathrm{R} 5$ were regarded as $\mathrm{CD} 4^{+} \mathrm{T}$ cells, where are cells in the region R3 and R6 as CD20+ B-cells. Cells in the regions $\mathrm{R} 4$ and $\mathrm{R} 7$ were regarded as monocytes, as summarized in Table 1.

Table 1 Blood cell subsets defining dot-plot regions and expressed cell surface molecules

\begin{tabular}{l|c|l}
\hline \multicolumn{1}{c|}{ Cells } & Dot-Plot Regions & \multicolumn{1}{c}{ Expressed Cell Surface Molecules } \\
\hline Platelets & R1 & HLA I, Nak (CD36), HNA-3a \\
Neutrophils & R2 & HLA I, HNA-1, HNA-2a, HNA-3a, HNA-4a, HNA-5a \\
CD4 ${ }^{+}$T-cells & R3 + R5 & HLA I, HNA-3a, HNA-5a \\
CD20+ B-cells & R3 + R6 & HLA I, HLA II, HNA-3a, HNA-5a \\
Monocytes & R4 + R7 & HLA I, HLA II, Nak ${ }^{\mathrm{a}}$ (CD36), HNA-3a, HNA-4a, HNA-5a \\
\hline
\end{tabular}

た, 同 HLA-DR 抗体を PerCP 標識ストレプトアビジン (BD Biosciences) を用いて染色し，その有無を確認し た.

\section{結 果}

1）ダメージを受けた血小板ないしその断片が, 非特 異的に好中球や CD20 陽性 B-リンパ球に結合する現象 に対する EDTA の効果

我々は 5 系統の血液細胞との反応パターンから，被 検血清中に含まれる白血球抗体の特異性を類推する FCM 法の開発を目的とし，まず，その条件の検討を行った. $\mathrm{ACD}$ 採血した全血をパネル細胞とし，PBS/BSA を洗
浄バッファーとしてそれぞれ用い, 前述の FCM 法(方 法3)参照）にて測定した（Fig. 2, Exp.1, 1st panel）. 細線はパネル細胞由来血清（陰性血清）のヒストグラ ムであり, 太線は新生児同種免疫性血小板減少症症例 由来の $\mathrm{Nak}^{\mathrm{a}}$ (CD36) に対する抗体を含む血清（特異性 は MPHA 法で決定)のそれである. 除性血清ではバッ クグラウンドを低く抑えることができたが， $\mathrm{Nak}^{\mathrm{a}}$ の抗 体を含む血清は, 本来 $\mathrm{Nak}^{\mathrm{a}}$ 抗原を発現している血小板 と単球だけではなく, 本来 $\mathrm{Nak}^{\mathrm{a}}$ 抗原を発現していない 好中球や CD20 陽性 B-リンパ球にも反応を示した (Fig. 2, Exp. 1, 1st panel).この原因について, 我々は, 溶 血過程に抒いて, 血小板 (血小板は $\mathrm{Nak}^{a}$ 抗原を強く発 


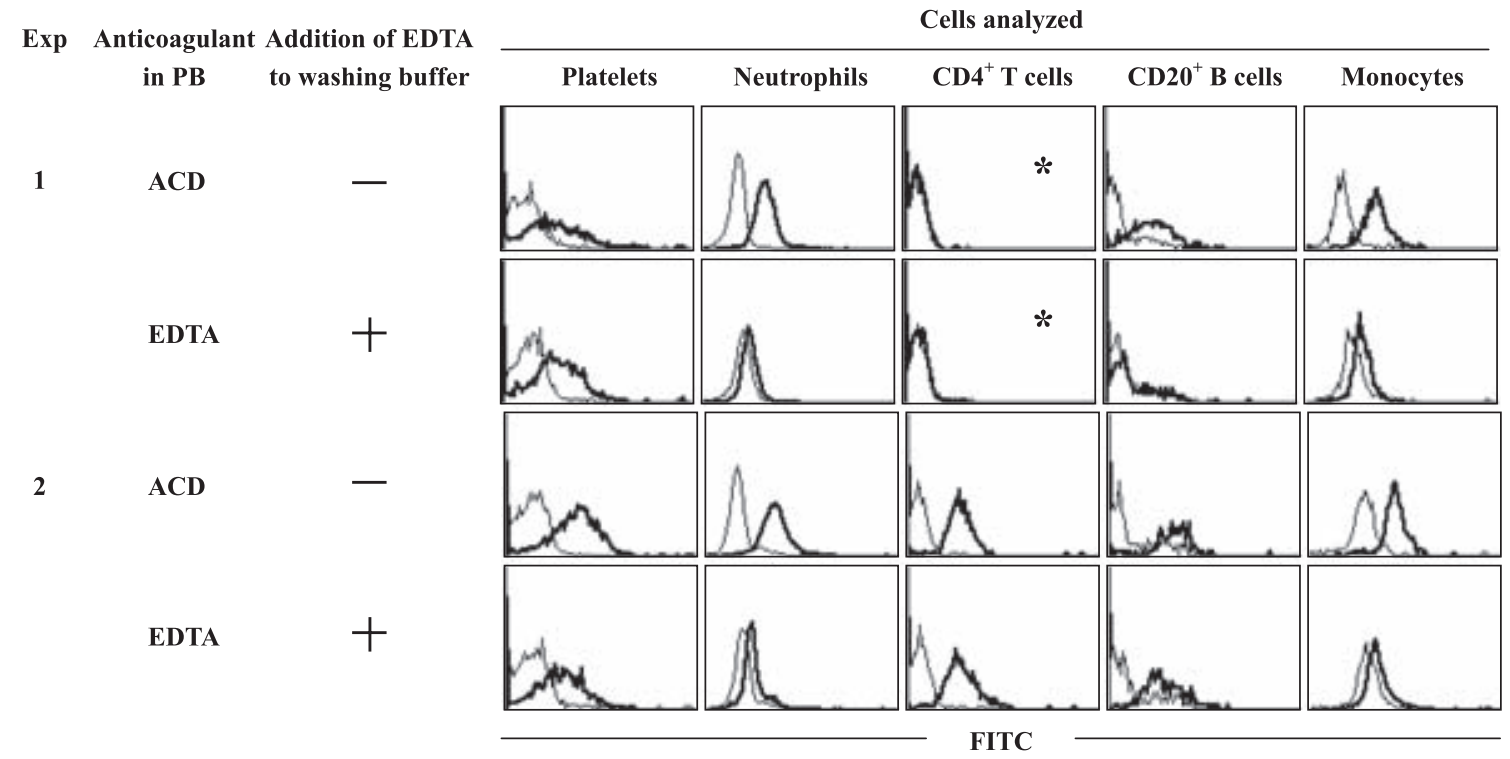

Fig. 2 Effects of ethylene diamine tetraacetic acid (EDTA) on nonspecific binding of putative-damaged platelets and/or their debris to neutrophils and $\mathrm{CD} 20^{+}$B-cells.

Thin lines and bold lines represent autologous negative-control serum and test serum, respectively. Asterisks mean that the thin line and the bold line were almost completely overlapped. The test serum was derived from the mother of a neonatal alloimmune thrombocytopenia case.

現している）がダメージを受け，その血小板ないしそ の断片が直接, 好中球や B-リンパ球に付着したのでは ないかと考えた。 そして, この現象を検証する為, 次 の実験を行った．精製した好中球に血小板を添加し， 溶血操作を行った場合と, 血小板を添加せずに溶血操 作を行った場合とで, 好中球に対する抗ヒト CD36 モノ クロナール抗体および抗ヒト CD41a モノクロナール抗 体の反応性の違いを比較した。 その結果，血小板を添 加しなかった場合, 抗ヒト CD36 モノクロナール抗体, 抗ヒト CD41a モノクロナール抗体ともに反応しなかっ たが，血小板を添加した場合は，両抗体ともに強く反 応した (Fig. 3).すなわち, Fig. 2, Exp.1, 1st panel の好中球に対する陽性反応は，溶血過程でダメージを 受けた血小板ないし，その断片の付着が原因と考えら れた. そこで, この血小板付着の問題を解決する為に, 試料を ACD 採血から EDTA 採血に変更し, さらに洗 浄バッファーである, PBS/BSA に 10mM EDTA を加 えたところ，この問題は解決した (Fig. 2, Exp. 1，2nd panel).この条件下では, 血小板および単球と上記 $\mathrm{Nak}^{\mathrm{a}}$ 抗血清との反応性を残したまま, 好中球, CD20 陽性 Bリンパ球との反応のみを抑えることが出来た. その際, 単球の反応性は減弱しているが，これは，おそらく単 球への血小板付着が抑えられたことに起因すると考え られる。ただし，好中球に非常に弱く残る反応性の原 因については不明である。次に上記改良した条件で, 他のパネル細胞と同血清との反応性についても調べた ところ (Fig. 2, Exp.2), このパネル細胞では血小板,

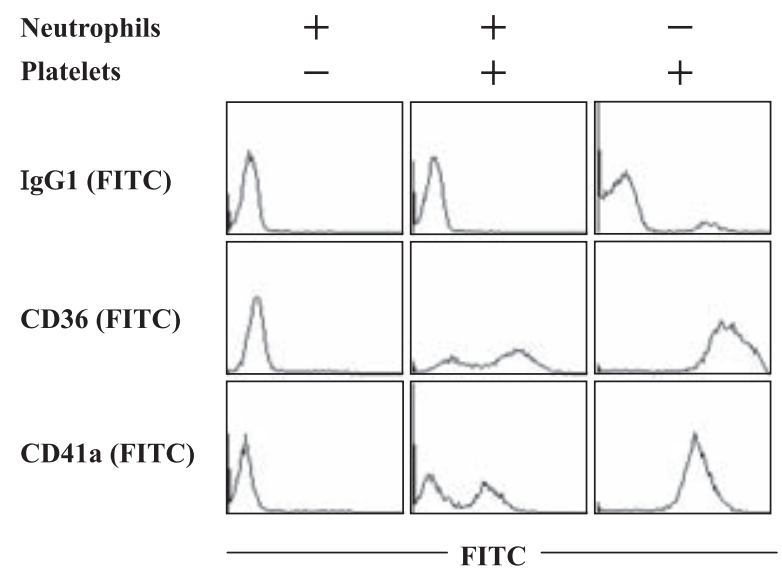

Fig. 3 Effects of the presence of platelets on neutrophil staining with anti-CD36 and anti-CD4la

Isolated neutrophils, isolated platelets or their combination were treated with red cell lysing solution and then stained with (FITC)-conjugated antibodies against CD36 and CD41a. In the left and middle columns, neutrophils were analyzed, while in the right column, platelets were analyzed.

単球のみならず, CD4 陽性 T-リンパ球と CD20 陽性 Bリンパ球は強く, 好中球には弱く反応した。この結果 から，同血清には $\mathrm{Nak}^{\mathrm{a}}$ 抗体のみならず，HLA Class I 抗体も含まれていると類推され, LABScreen ${ }^{\circledR}$ 法で HLA 抗体検査を実施したところ, HLA-A11，A26，B7，

B48，B60，B61 の特異性を持つ抗体が検出された. 2nd panel の HLA Class I タイプは HLA-A24, 30 ; B13, 48 ; Cw8, 15 であった為に, 好中球や CD4 陽性 T-リン 


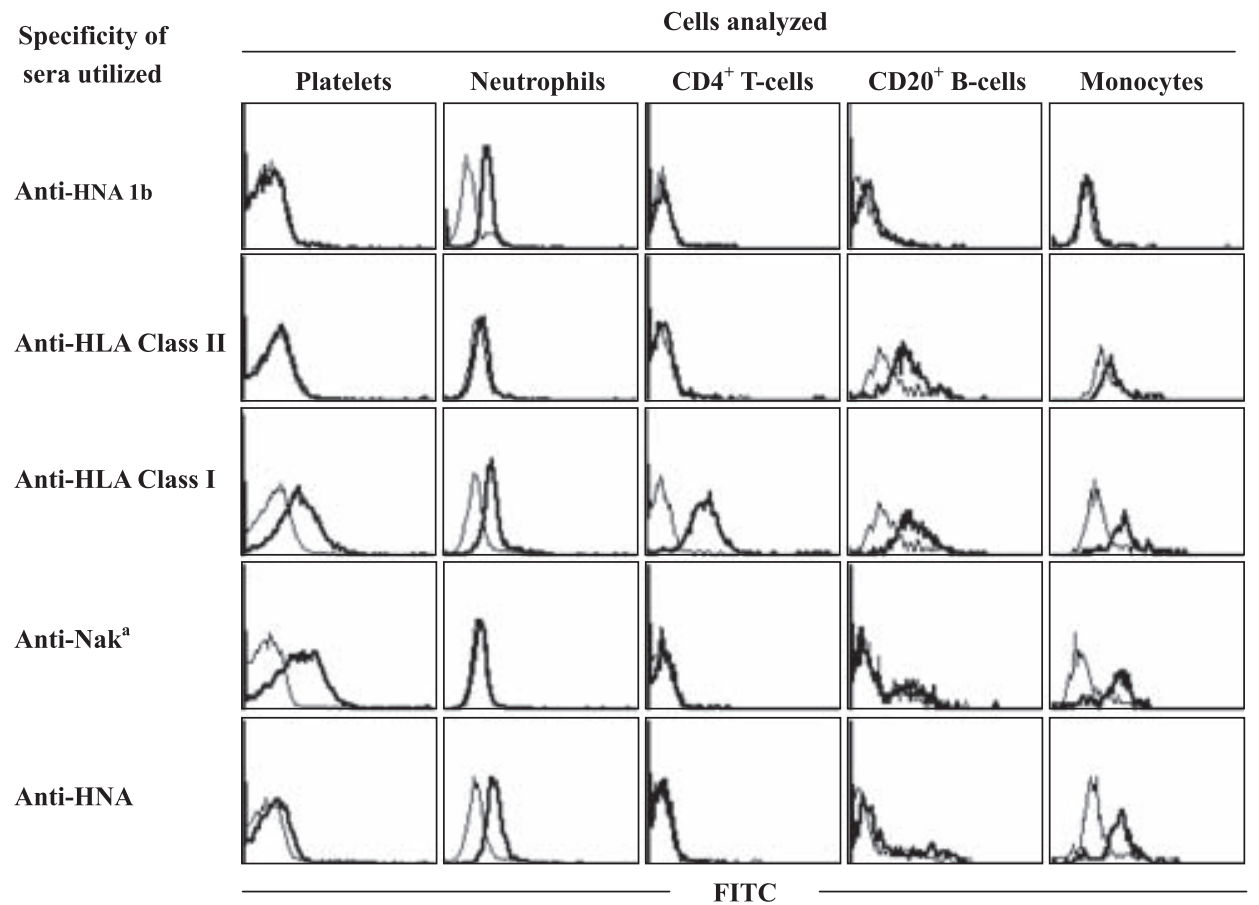

Fig. 4 Representative examples of simultaneous whole blood five cell lineage staining analysis. The test serum samples were derived from a patient of nonhemolytic transfusion reaction (1st panel), a patient of nonhemolytic transfusion reaction (2nd panel), a patient refractory to platelet transfusion (3rd panel), the mother of a case of neonatal alloimmune thrombocytopenia (4th panel), and a case of possible transfusion-related acute lung injury (5th panel).

パ球, CD20 陽性 B-リンパ球に反応し, 1st panel の HLA Class Iタイプは HLA-A24, - ; B5102, $54 ; \mathrm{Cw} 6,8$ であった為に，好中球，CD4 陽性 T-リンパ球，CD20 陽性 B-リンパ球に反応しなかったと考えられる.

以上の結果から, EDTA を用いることにより, 非特 異的結合が抑制された事が示唆された，従って，以降 の実験は, 試料を EDTA 全血に, 洗浄バッファーはPBS/ BSA/EDTA にして行なった.

\section{2）白血球抗体の検出}

Fig. 4 に本法における各種白血球抗体陽性血清の反応 を示した. 1 段目のヒストグラムは, 非溶血性輸血副作 用症例由来の血清を用いた. LABScreen ${ }^{\circledR}$ 法により,こ の血清から HLA-B37，B38，B51，B52，B27，B44, B53，B49 の特異性を持つ HLA Class I 抗体が検出され た.その為, 同血清中の HLA Class I 抗体と反応しない パネル細胞を用いて本法を実施した。その結果, HNA$1 \mathrm{~b}$ 抗原陽性パネル細胞の好中球との反応は観察された が(Fig. 4 1st panel), HNA-1b 抗原陰性パネル細胞の 好中球との反応は観察されなかった (data not shown). 尚, Fig. 4 1st panel に使用したパネル細胞は HNA-1b 抗原陽性で, HLA Class I タイプは HLA-A26 - ; B35, 60；Cw9，一である. 2 段目のヒストグラムは前述とは 別の非溶血性輸血副作用症例由来の血清を用いた. LABScreen ${ }^{\circledR}$ 法により この血清から HLA-DR52 の特異性を
持つ HLA Class II 抗体が検出された，そして，同血清 を本法で測定したところ, HLA-DR52 抗原陽性パネル 細胞においては, CD20 陽性 B-リンパ球と単球に反応が 観察され, 血小板, 好中球, CD4 陽性 T-リンパ球には 反応が観察されなかった（Fig.4 2nd panel）.

また，HLA-DR52 抗原陰性パネル細胞の CD20 陽性 B-リンパ球や単球において, 反応が観察されなかった (data not shown). 3 段目のヒストグラムは血小板輸血 不応答症例患者由来の血清を用いた。この血清は B51 と B61 の特異性を持つ HLA Class I 抗体を有しており (特異性は AHG-LCT 法で決定), HLA B51 またはB61 抗原陽性パネル細胞では, 5 系統全ての血液細胞との反 応が観察されたが(Fig. 4 3rd panel), B51 またはB61 抗原陰性パネル細胞の血液細胞では, その反応は観察 されなかった (data not shown). 4段目のヒストグラ ムは Fig. 2 に示した血清とは異なる, 新生児同種免疫性 血小板減少症症例より検出された $\mathrm{Nak}^{\mathrm{a}}$ の特異性を有す る血清を用いた。この血清は $\mathrm{Nak}^{a}$ 抗原陽性パネル細胞 の血小板と単球に，その反応性が観察された（Fig. 4 4th panel)。 そして, 今回デー夕は示さないが, HPA1a の特異性を持つ血清に扔いては, HPA-1a 抗原陽性パ ネル細胞の血小板にのみ, その反応性が観察された。 5 段目のヒストグラムは possible TRALI 症例由来の血 清を用いた. LABScreen ${ }^{\circledR}$ 法による HLA 抗体検查の結 


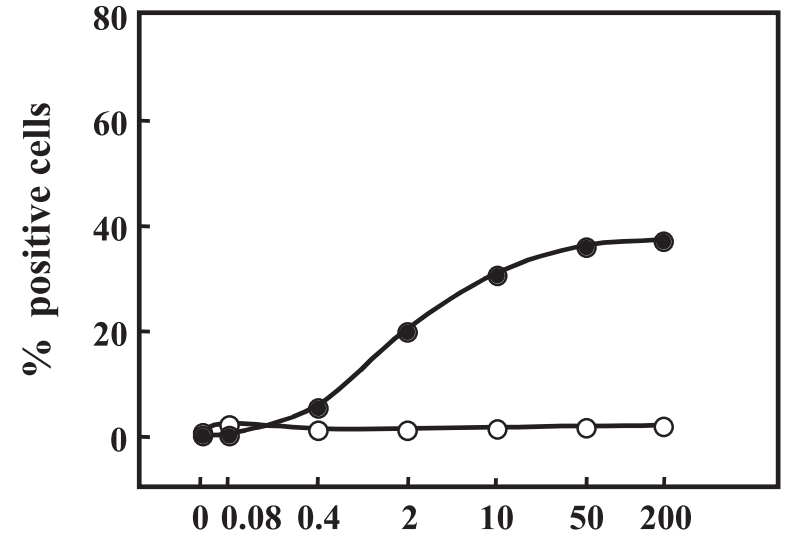

Conc. of anti-human HLA-DR $(\mu \mathrm{g} / \mathrm{ml})$

Fig. 5 Binding of putative immune complex to neutrophils.

Ethylene diamine tetraacetic acid (EDTA) whole blood was incubated with biotin-conjugated mouse anti-human leucocyte antigen (HLA) DR monoclonal antibody. The amounts of the anti-HLA DR antibody bound on neutrophils (open circle) and lymphocytes (closed circle) were identified by streptoavidin-PerCP.

果, 同血清中から HLA Class I, HLA Class II 抗体は検 出されなかった．また，本法において，10種類以上の パネル細胞を用いた測定の結果, 約半分のパネル細胞 においては好中球と単球に, $1 / 3$ のパネル細胞において は単球にのみ反応したが，同血清の特異性の同定には 至らなかった，今後，更なる検討を続けたい．

\section{3）細胞表面に付着した immune complex の検出}

本法は試料として, 多数の血漿タンパク質や可溶型 HLA 分子を含んだ全血 ${ }^{16)}$ 用いる検查法である. それ 故, それら血漿タンパク質や可溶型 HLA 分子と被検血 清中の抗体が immune complex を形成し，その形成さ れた immune complex が, 細胞表面上の FcyRIIA を介 して, 好中球に結合することは, 十分に考えられる ${ }^{192020}$. これは，抗体特異性を決定する際に，大きな問題とな る.そこで我々は, パネル細胞として用いるEDTA 採血した全血に, マウス由来抗ヒト HLA-DR モノクロ ナール抗体を加え, 血槳中に含まれる可溶型 HLA-DR 抗原と同抗体により, immune complex を形成させ, そ れが好中球に結合するか否かを測定した ${ }^{21}$. その結果, 全血に抗ヒト HLA-DR モノクロナール抗体を添加する ことで, 同抗原を発現するリンパ球では抗体の結合が 観察され，その結合は添加した抗体濃度依存的なもの であった (Fig. 5). 一方, HLA-DR 抗原の発現のない 好中球では同抗体もしくは, immune complex の結合は 認められなかった(Fig. 5)，以上の結果より，本法は全 血と血清を混合することで生じるであろう immune complexの影響を受けないと考えられた.

\section{考察}

我々は, 全血を試料とし, 低バックグラウンドで, F c rR I 除去操作が不要でから, 5 系統の血液細胞を同時 に測定する FCM 法の樹立に成功した. 今回の研究では IgG 性の白血球抗体の検出に焦点を絞ったが, 本法にお いて, 2 次抗体を抗ヒト IgMに替えることで, IgM 性の抗体の検出も可能であった (data not shown). し かし，本法には克服しなければならない問題もある. 1つ目の問題点として, 被検血清中に HLA Class I 抗体 と, それ以外の特異性を有する白血球抗体が混在した 場合, HLA Class I 抗体は全ての血液細胞と反応するた め, 混在するその他の HLA Class II 抗体や単球抗体等 の検出が困難になることである。この問題を解決する 方法として, 最初に, 本法以外の検查法で, 被検血清 中に含まれる HLA Class I 抗体の特異性を予め同定し, 同抗体と反応しない HLA タイプのパネル細胞を選択し 準備する必要がある。本研究において, HLA Class I 抗体に反応しないパネル細胞を選択し，本法を実施し た例は Fig. 4 1st panelである.この例においては, HLA Class I 抗体に反応しないパネル細胞の入手が可能であっ たが, 被検血清中に含まれる HLA Class I 抗体の特異性 が広範囲で, その抗体に反応しないパネル細胞の入手 が困難である場合，プール血小板を用いて HLA Class I 抗体を吸収するのも解決方法の一つである ${ }^{22}$.

2 つ目の問題点として, 本法を用いて解析した TRALI 症例が possible TRALI 1 例のみであった事や, Fig. 4 5th panel に示した様に, 特異性が同定できない例が存 在する事である.この問題点を解決すれば, 本法がTRALI 関連抗体の検出㧍よびその特異性の同定に有用な検査 法として，支持されると期待している.

我々は白血球抗体のスクリーニングを実施するにあ たり, まず, 最初に LABScreen ${ }^{\circledR}$ 法で HLA 抗体検查を 実施している. その結果, HLA Class I 抗体が検出され た場合は，その特異性を同定し，次に本法で被検血清 に含まれる HLA Class I 抗体に反応しない, HNA-1 および HNA-2a 既知パネル細胞を用いて好中球や単球 等に対する抗体検査を実施している. 当センターは HLA Class I タイプ既知の成分献血登録済献血者を 2 万人以 上保有し, その中から, 1 日に 30 から 40 人以上の成分 献血登録済献血者に献血のご協力を頂いている，その 為, 被検血清中に HLA Class I 抗体が含まれる場合にお いても，その抗体に反応しないパネル細胞を選択する 事は，ほとんどの事例において可能である.しかし， 前述した様に, パネル細胞の入手が困難な場合はプー ル血小板で HLA Class I 抗体を吸収する事が必要になる と考えられる。

現在, 本法以外にも白血球抗体, とりわけ好中球抗 


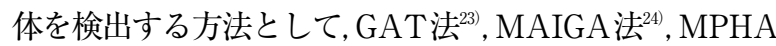
法25)等が知られている. しかし, いずれの方法も好中球 にのみ注目しており，他の血液細胞に対する反応性を 確認することはできない，他の血液細胞に対する反応 性のプロファイル情報は，その抗体の特異性の同定に 非常に有用である. 例えば, HNA 抗体のうち HNA-3, HNA-4, HNA-5，等がそれに当たる（Table 1).

一方, 本法は $50 \mu l$ の全血に被検血清を $10 \mu l$ 加えてい る, この条件は循環血液量 $5 l$ の患者に対して, 白血球 抗体を含んだ $1 l$ の新鮮凍結血漿（FFP）または血小板 製剤を輸血した事になり,この割合は非現実的である. 循環血液量 $5 l$ の患者が輸血する血液製剤の量は FFP 2 単位であれば約 $160 \mathrm{ml}$, 血小板製剤であればおおよそ 150 から $200 \mathrm{ml}( \pm 50 \mathrm{ml})$ である．輸血の状況を再現す るのであれば, $50 \mu l$ の全血に対して, 被検血清が 1 2 $\mu l$ もしくは 10 倍希釈した被検血清を $10 \sim 20 \mu l$ 加える事 となり，この条件下で，好中球や単球，血小板上に抗 体が結合するなら，この抗体は生体内でも当該血液細 胞に結合しうるであろう. 実際, Fig. 4 の 1st panel, 4 th panel, 5th panelに用いた血清は, 上記条件において, 標的となる血液細胞との結合が認められた（data not shown).ささらに, 標的細胞に抗体が結合した場合には, 細胞の活性化が起こり,TRALI を含めた非溶血性輸血 副作用に繋がって行く可能性が考えられる。この事に 関連する報告として, TRALI 関連抗体が単球を活性化 させ, IL-1，TNF- $\alpha$ 等を放出させた報告や ${ }^{10}$, 好中球抗 体が好中球を活性化させた報告34426), さらに, 血小板抗 体が血小板を活性化させた報告 ${ }^{27228}$ があり,これらは血 液製郕中の白血球抗体の特異性を同定するより，むし ろ抗体と患者血液細胞との結合を明らかにすることが 重要であることを示している.

現在，我々は，上記血清以外でも，同条件で抗体の 結合が認められる HLA Class I 抗体を保有しており,こ れらの血清が血液細胞を活性化する否かを検討してい るところである。

\section{文献}

1) Kleinman $S$, Caulfield $T$, Chan $P$, et al: Toward an understanding of transfusion-related acute lung injury: statement of a consensus panel. Transfusion, 44: 1774-1789, 2004.

2) Goldman M, Webert KE, Arnold D.M, et al: Proceedings of a consensus conference: Towards an understanding of TRALI. Transfusion Med Rev, 19: 2-31, 2005.

3) Popovsky M.A, Abel M.D, Moore S.B, et al: Transfusionrelated acute lung-injury associated with passive transfer of antileukocyte antibodies. Am Rev Respir Dis, 128: 185-189, 1983.
4) Popovsky M.A., Moore S.B: Diagnostic and pathogenetic considerations in transfusion-related acute lung injury. Transfusion, 25: 573-577, 1985.

5) Kopko P.M, Popovsky M.A, MacKenzie M.R, et al: HLA class II antibodies in transfusion-related acute lung injury. Transfusion, 41: 1244-1248, 2001.

6) Flesch B.K, Neppert J: Transfusion-related acute lunginjury caused by human leucocyte antigen class II antibody. Br J Haematol, 116: 673-677, 2002.

7) Varela M, Mas A, Nogues N, et al: TRALI associated with HLA class II antibodies. Transfusion, 42: 1102, 2002.

8) Nishimura M, Mitsunaga S, Ishikawa Y, et al: Possible mechanisms underlying development of transfusionrelated acute lung injury: roles of anti-major histocompatibility complex class II DR antibody. Transfusion Med, 13: 141-147, 2003

9) Win N, Brown C, Navarrete C, et al: TRALI associated with HLA class II antibodies. Transfusion, 43: 545-546, 2003.

10) Kopko P.M, Paglieroni T.G, Popovsky M.A, et al: TRALI: correlation of antigen-antibody and monocyte activation in donor-recipient pairs. Transfusion, 43: 177-184, 2003.

11) Verheugt F.W, von dem Borne A.E, Decary F, et al: The detection of granulocyte alloantibodies with an indirect immunofluorescence test. Br J Haematol, 36: 533-544, 1977.

12) Kuijpers R.W, Dooren M.C, von dem Borne A.E, et al: Detection of human monocyte-reactive alloantibodies by flow cytometry after selective downmodulation of the Fc receptor I. Blood, 78: 50-56, 1991.

13) Nerad J.L, Griffiths J.K, van der Meer J.W, et al: Interleukin-1b (IL-1b), IL-1 receptor antagonist, and TNF-a production in whole blood. Journal of Leukocyte Biology, 52: 687-692, 1992.

14) Bouma M.G, Jeunhomme T.M, Boyle D.L, et al: Adenosine inhibits neutrophil degranulation in activated human whole blood. Journal of Immunology, 158: 54005408, 1997.

15) Huizinga T.W, de Haas M, Kleijer M, et al: Soluble Fcg receptor III in human plasma originates from release by neutrophils. Journal of Clinical Investigation, 86: 416423, 1990.

16) Ghio M, Contini P, Mazzei C, et al: Soluble HLA class I, HLA class II, and Fas ligand in blood components: a possible key to explain the immunomodulatory effects of allogeneic blood transfusions. Blood, 93: 1770—1777, 1999.

17) Johnson A.H, Rossen R.D, Butler W.T, et al: Detection of 
alloantibodies using a sensitive antiglobulin microcytotoxicity test: identification of low levels of pre-formed antibodies in accelerated allograft rejection. Tissue Antigens, 2: 215-216, 1972.

18) Shibata Y, Juji T, Nishizawa Y, et al: Detection of platelet antibodies by a newly developed mixed agglutination with platelets. Vox Sanguinis, 41: 25-31, 1981.

19) Ravetch J.V, Kinet J.P: Fc receptors. Annual Review of Immunology, 9: 457-492, 1991.

20) Hart S.P, Alexander K.M, Dransfield I: Immune complexes bind preferentially to FcgRIIA (CD32) on apoptotic neutrophils, leading to augmented phagocytosis by macrophages and release of proinflammatory cytokines. Journal of Immunology, 172: 1882-1887, 2004.

21) Hart S.P, Jackson C, Kremmel LM, et al: Specific binding of an antigen-antibody complex to apoptotic human neutrophils. American Journal of Pathology, 162: 10111018, 2003.

22) Prou O, Kaplan C, Muller J.Y: Freeze dried platelets for HLA alloantibodies absorption. Tissue Antigens, 16: $105-107,1980$.

23) Jiang A.F, Lalezari P: A micro-technique for detection of leukocyte agglutinins. Journal of Immunological
Methods, 7: 103-108, 1975.

24) Bux J, Kober B, Kiefel V, et al: Analysis of granulocytereactive antibodies using an immunoassay based upon monoclonal antibody-specific immobilization of granulocyte antigens. Transfusion Medicine, 3: 157-162, 1993.

25) Araki N, Nose Y, Kohsaki M, et al: Anti-granulocyte antibody screening with extracted granulocyte antigens by a micro-mixed passive hemagglutination method. Vox Sanguinis, 77: 44-51, 1999.

26) Silliman C.C, Thurman G.W, Ambruso D.R: Stored blood components contain agents that prime the neutrophil NADPH oxidase through the platelet-activation factor receptor. Vox Sanguinis, 63: 133-136, 1992.

27) Taylor S.M, Reilly M.P, Schreiber A.D, et al: Thrombosis and shock induced by activating antiplatelet antibodies in human FcgRII transgenic mice: the interplay among antibody, spleen, and Fc receptor. Blood, 96: 4254-4260, 2000.

28) Wakamoto S, Fujihara M, Urushibara N, et al: Heterogeneity of platelet responsiveness to anti-CD36 in plasma associated with adverse transfusion reaction. Vox Sanguinis, 88 : $41-51,2005$.

\title{
SIMULTANEOUS FIVE CELL-LINEAGE FLOW CYTOMETRIC ANALYSIS SYSTEM FOR DETECTION OF LEUCOCYTE ANTIBODIES
}

\author{
Nobuki Matsuyama ${ }^{1)}$, Yoshitaka Kojima ${ }^{1)}$, Fumiya Hirayama ${ }^{1)}$, Kazuta Yasui $^{1)}$, Atsuko Taniue ${ }^{1)}$, \\ Yasuo Fukumori $^{1)}$, Keiji Yoshimura ${ }^{1)}$, Nobutada Tabata ${ }^{2)}$, Naomi Sakata ${ }^{2)}$, \\ Yoshihiko Tani ${ }^{11}$ and Hirotoshi Shibata ${ }^{1)}$ \\ ${ }^{1)}$ Japanese Red Cross Osaka Blood Center \\ ${ }^{2)}$ Department of Pediatrics, Kinki University School of Medicine
}

\section{Keywords:}

five-cell lineage, flow cytometry, leucocyte antibody, whole blood

(C)2007 The Japan Society of Transfusion Medicine and Cell Therapy Journal Web Site: http://yuketsu.gr.jp 